\title{
From Gospel to Gates: Modal Blending in African-American Musical Discourse before the Signifyin(g) Monkey
}

\author{
Christopher Coady, Sydney Conservatorium of Music
}

The 1988 publication of Henry Louis Gates's The Signifyin(g) Monkey: A Theory of African-American Literary Criticism provided a new analytical tool for the study of African-American music. While Gates's primary concern was to the literary arena, his deconstruction of the cultural act of 'Signifyin(g),' a rhetorical process utilizing figurative speech and double talk, was immediately seen to have implications for the study of formal processes in African-American music. Over the past 20 years, artists as diverse as funk bandleader James Brown, iconic jazz trumpeter Miles Davis and orchestral composer William Grant Still, have all met academic assessment through the lens of Gates's theory. And while Gates bears responsibility for catapulting the idea of metaphorical communication to the forefront of African-American music studies, it is important to acknowledge that this cross-over success would not have been nearly as total if not for the efforts of people documenting linguistic/musical parallels in AfricanAmerican culture decades earlier. This article highlights the manner in which these earlier works set the stage for the application of Gates’s theory to the musical realm.

In The Signifyin(g) Monkey, Gates traces the roots of African-American Signifyin(g) to the rhetorical tropes of a shared trickster figure prevalent in the folklore of Nigeria, Benin, Cuba, Haiti, South America and the USA (Gates 1988: 4). He refers to the figure by its Yoruba name, Esu-Elegbara, but argues that the archetype is encoded in, among others, the figures Exfi in Brazil, Echu-Elegua in Cuba, and Papa Legbas in Haiti (Gates 
1988: 5). The geographic dissemination of the archetype is linked to the cross-cultural milieu of the trans-Atlantic slave trade and while incarnations of the figure are often modified physically, its propensity for rhetorical strategies involving ambivalent speech is manifest universally. In Yoruba culture, the figure presents as an interpreter between God and man. He is responsible for decoding the texts of Ifa, 'the god of determinate meanings' (Gates 1988: 21), during the process of divination. Esu's interpretation is complicated however by 'the human being's curse of ... indeterminacy or uncertainty of fate' (21). This results in enigmatic translations full of double meanings. In practice, the enigma is often further interpreted by the 'babalawo' (diviner) for the benefit of the client yet the message is understood by both to remain indeterminate at its core.

In the pan-African diaspora, Esu archetypes tend to deliver their ambiguous messages in the context of 'sacred myths as do characters in a narrative' (Gates 1988: 52). The African-American permutation of Esu however appears in contrast as an overarching narrative voice. Gates holds that:

\footnotetext{
Esu's functional equivalent in Afro-American profane discourse is the Signifying Monkey, a figure who seems to be distinctly Afro-American, probably derived from Cuban mythology, which generally depicts Echu-Elegua with a monkey at his side. Unlike his Pan-African Esu cousins, the Signifying Monkey exists in the discourse of mythology not primarily as a character in a narrative but rather as a vehicle for narration itself. (52)
}

The mode of discourse Gates refers to in this quote can be observed in the multiple settings of the 'Signifying Monkey,' an African-American toast, or oral narrative, in which the rhetorical strategy of misrepresentation plays an ubiquitous role. The following version of the toast text is taken from Goss and Barnes's (1989) Talk that Talk: An Anthology of African-American Storytelling and is re-printed below in its entirety:

\footnotetext{
Said the signifyin' monkey to the lion one day:

"Hey, dere's a great big elephant down th' way

Goin' 'roun' talkin,' I'm sorry t' say,

About yo' momma in a scandalous way!’

“Yeah, he’s talkin' 'bout yo’ momma an’ yo’ grandma, too;

And he don' show too much respect fo' you.

Now, you weren't there an' I sho' am glad

'Cause what he said about yo' momma made me mad!’

Signifyin’ Monkey, stay up in yo’ tree

You are always lyin' and signifyin'

But you better not monkey wit' me.
} 
The lion said, "Yea? Well, I’ll fix him; I'll tear that elephant limb from limb."

Then he shook the jungle with a mighty roar

Took off like a shot from a forty-four.

He found the elephant where the tall grass grows

And said, "I come to punch you in your long nose."

The elephant looked at the lion in surprise

And said, "Boy, you better go pick on somebody your size.”

But the lion wouldn't listen; he made a pass;

The elephant slapped him down in the grass.

The lion roared and sprung from the ground

And that's when that elephant really went to town.

I mean he whupped that lion for the rest of the day

And I still don't see how the lion got away

But he dragged on off, more dead than alive,

And that's when that monkey started his signifyin' jive.

The monkey looked down and said, "Oooh wee!

What is this beat-up mess I see?

Is that you, Lion? Ha, ha! Do tell!

Man, he whupped yo’ head to a fare-thee-well!"

“Give you a beatin' that was rough enough;

You s'pposed to be the king of the jungle, ain't dat some stuff?

You big overgrown pussycat! Don' choo roar

Or I'll hop down there an' whip you some more.”

The monkey got to laughing and a’ jumpin' up and down,

But his foot missed the limb and he plunged to ground,

The lion was on him with all four feet

Gonna grind that monkey to hamburger meat.

The monkey looked up with tears in his eyes

And said, "Please Mr. Lion, I apologize,

I meant no harm, please, let me go

And I'll tell you something you really need to know.”

The lion stepped back to hear what he'd say,

And that monkey scampered up the tree and got away.

"What I wanted to tell you," the monkey hollered then,

"Is if you fool with me, I'll sic the elephant on you again!"

The lion just shook his head, and said, "You jive...

If you and yo' monkey children wanna stay alive,

Up in them trees is where you better stay."

And that's where they are to this very day.

Signifyin’ Monkey, stay up in yo’ tree

You are always lyin' and signifyin'

But you better not monkey wit’ me. (Goss \& Barnes 1989: 456-457)

In the toast, the monkey can be seen to persuade the lion through misrepresentation

twice. In the first instance, the lion is driven to attack the elephant either through the

fabrication or the manipulation of the elephant's comments about the lion's family as 
related to him by the Signifyin(g) Monkey. Distressed after being trampled by the elephant, the lion attacks the monkey in an act of revenge. At this point, the monkey commits his second act of misrepresentation, convincing the lion to let him go with the promise of relaying a secret he 'really need[s] to know.' The secret ultimately ends up being to the lion's detriment: 'If you fool with me, I'll sic the elephant on you again!' The use of this rhetorical strategy not only drives the action of the text, it demonstrates the potential for ambivalent speech to serve as a strategic device in the subversion of established power structures.

Gates uses the African-American term 'Signifyin(g)' to refer to the spectrum of devices that comprise the rhetorical approach of the monkey in this toast. The term is a homonym for the English language word 'signifying' and its etymology remains unclear; Gates places it ‘anonymously and unrecorded in antebellum America’ (Gates 1988: 46). He explains the difference between the English and African-American vernacular terms as follows:

\footnotetext{
The English-language use of signification refers to the chain of signifiers that configure horizontally, on the syntagmatic axis. Whereas signification operates and can be represented on a syntagmatic or horizontal axis, Signifyin(g) operates and can be represented on a paradigmatic or vertical axis. Signifyin(g) concerns itself with that which is suspended, vertically: the chaos of what Saussure calls "associative relations," which we can represent as the playful puns on a word that occupy the paradigmatic axis of language and which a speaker draws on for figurative substitutions. These substitutions in Signifyin(g) tend to be humorous, or function to name a person or a situation in a telling manner. Whereas signification depends for order and coherence on the exclusion of unconscious associations which any given word yields at any given time, Signification luxuriates in the inclusion of the free play of these associative rhetorical and semantic relations. (49)
}

Simply put, 'signifying’ operates in a linear manner as a cause and effect relationship; there can be only one meaning for something that is signified. The act of 'Signifyin(g),' by contrast, necessitates multiple meanings. It is the process of saying two or more things at once. This act, according to Gates, serves as 'the rhetorical principle' of 'African American vernacular discourse' (44). It is the 'trope of tropes,' the overarching 'figure for black rhetorical figures' (51), and the universal 'double-voiced utterance' that allows for a charting of 'discrete formal relationships' imbedded throughout the scope of 'African-American literary history’ (88). 
While Gates's theory is the first to assign such overarching status to Signfiyin(g), ${ }^{1}$ he is not the first scholar to attempt a definition of the term. Abrahams (1964) had earlier endeavoured to set parameters on the word's meaning by cataloguing its many occurances:

\begin{abstract}
The term "signifying" seems to be characteristically Negro in use if not in origin. It can mean any of a number of things; in the case of the toast [The Signifying Monkey] it certainly refers to the monkey's ability to talk with great innuendo, to carb, cajole, neddle and lie. It can mean in other instances the propensity to talk around a subject, never quite coming to the point. It can mean "making fun" of a person or situation. Also it can denote speaking with the hands and eyes, and in this respect encompasses a whole complex of expressions and gestures. Thus it is "signifying" to stir up a fight between neighbours by telling stories; it is signifying to make fun of the police by parodying his motions behind his back; it is signifying to as for a piece of cake by saying, "My brother needs a piece of that cake.” It is, in other words, many facets of the smart alecky attitude. (Abrahams 1964: 52)
\end{abstract}

Abrahams's list of Signifyin(g) events is expansive, and although it touches on the ambiguous principles of the trope viewed to be paramount by Gates, his emphasis seems less on rhetorical function and more on a general aesthetic of 'naughtiness.' Of particular interest is Abrahams's claim that engaging in obscured mock gestures of authority figures is typical of Signifyin(g) behaviour. Mitchell-Kernan critiques this aspect of Abrahams's definition, claiming that 'many would label the parodying of the policeman’s motions ‘marking’’ (Mitchell-Kernan 1972: 310), an entirely different approach to commentary in African-American discourse involving the use of caricature rather than semantic play.

Mitchell-Kernan's understanding of the trope instead places Signifyin(g) squarely in the realm of metaphorical communication. Equal weight is placed on both the Signifier's assembly of words and their interpretation by the intended audience. Only after successful decoding has occurred does Mitchell-Kernan believe an act of Signifyin(g) has taken place. She explains: 'A precondition for the application of 'signifying' to some speech act is the assumption that the meaning decoded was consciously and purposely formulated at the encoding stage’ (Mitchell-Kernan 1972: 312). This act of communication relies heavily on the recipient's ability to reassemble the contextual relationships implied by the Signifier:

The hearer is thus constrained to attend to all potential meaning-carrying symbolic systems in speech events - the total universe of discourse. The context embeddedness of meaning is attested

\footnotetext{
${ }^{1}$ The word Signifyin(g) will appear without quotation marks from this point forward. I have adopted Gates's spelling in an effort to clarify usage of the respective homonyms.
} 
to by both our reliance on the given context and, most important, by our inclination to construct additional context from our background knowledge of the world. (Mitchell-Kernan 1972: 311)

This reading of the trope is further supported by Geneva Smitherman's claim that Signifyin(g) necessarily requires direct engagement with the person signified upon:

Signification has the following characteristics: indirection, circumlocution; metaphoricalimagistic (but images rooted in the everyday, real world); humorous, ironic; rhythmic fluency and sound; teach but not preachy; directed at person or persons usually present in the situational context (siggers do not talk behind yo back); punning, play on works; introduction of the semantically or logically unexpected. (Smitherman 1977: 121)

Smitherman's support of the communicative primacy of the trope is evident in her claim that 'siggers do not talk behind yo back.' 2 The communicative aspect is combined with its educative properties ('teach but not preachy') and its double voiced tendency to create a rhetorical linguistic device and it is this unified process that Gates views as paramount in the construction of African American literary works.

It must be noted, however, that Gates's reliance on this trope as a fundamental organisational construct was not only unique, but was highly contentious. Myers (1990) takes aim at what he perceives to be Afro-Centrism in Gates's work, apparent in Gates’s failure to detach the literary device of Signifyin(g) from the racial domain:

\begin{abstract}
The sad fact is that Gates's intentions in The Signifying Monkey are mutually exclusive. Gates cannot specify principles of interpretation inside the black tradition without simultaneously upsetting the whole notion of "black difference" upon which the claim for a black tradition rests. For once a principle is stated it becomes literary, available to any number of writers and critics, and not merely to blacks. Gates recognizes this. As a "principle of language use," he says, signifying is "not in any way the exclusive property of black people ..." To his credit, then, Gates perceives that it would be an error to ascribe the unique characteristics of Afro-American literature to race. But he is not sure what else to ascribe them to. His reasoning runs in circles. Black writers form a tradition. How do you know? They all use the "trope" of signifying. What makes this trope distinctively black? All black writers use it. (Myers 1990: 63)
\end{abstract}

The circularity mentioned by Myers does prove to be problematic if participation in the African-American literary tradition remains exclusively tied to race. At issue is the question of whether a non African-American can contribute to the tradition or whether participation in this tradition requires racial pedigree. Similar questions arose in early jazz discourse and have been partly answered through the process of canonization. With the benefit of a constructed jazz history (DeVeaux 1991) an apparent consensus now

\footnotetext{
${ }^{2}$ Smitherman uses the term 'siggers' in reference to those who employ the Signifyin(g) trope. The term is an obvious conflation of a familiar racial slur and the word Signifyin(g). Unsurprisingly, a plurality of associations emerge from this pairing, including an acknowledgment of an environment hostile to African American progress and a simultaneous nod towards the reappropriation of objects of oppression in the preservation of African-American culture.
} 
exists that the genre remains both grounded in the aural tradition of African-

Americans_-discussed at length by Berliner (1994) — and simultaneously open to the contributions of artists other than African-Americans (Atkins 2001; Jones 2001;

Austerlitz 2005). ${ }^{3}$ If there are parallels between the African-American literary and music traditions (and as discussed in the next section of this paper, Gates assures us there are), then it seems plausible that the literary tradition might also be embraced and developed by non African-Americans.

Yet another facet of the Afro-Centric critique calls into question the African-American origins of the Signifyin(g) trope itself. Fenstermaker (2008) views the act as closely related to what Linda Hutcheon (1989) refers to as 'complicitous critique,' a device through which an author 'draws on a historical figure or event and simultaneously undermines the historical accuracy of that representation' in an effort to highlight 'the ideology behind that representation' (Fenstermaker 2008: 1). She goes on to assert that 'whether one calls the artistic process "complicitous critique” or Signifyin(g), the term one uses is, to some extent, dependent upon the author's race' (Fenstermaker 2008: 1). While these devices may appear similar in the written word, it should be noted that the first level of Signifyin(g) in African-American literature emerges from the transposition of an oral tradition on to written narrative. This is a unique facet of the device and an origin quite different from that of 'complicitous critique.' The connection of the device's literary use to the rhetorical tropes of African-American speech may not definitively establish all uses of Signifyin(g) as grounded in African-American culture, but it does speak strongly to the culture's affinity for and facility over the device’s application.

Indeed, there can be little doubt that Signifyin(g) is a rhetorical trope embraced in African-American spoken vernacular. Abrahams (1964), Mitchell-Kernan (1972) and Smitherman (1977) all draw on interviews and personal anecdotes from the AfricanAmerican community to illustrate their multi-faceted definitions of the device. The role of Signifyin(g) in interpreting African-American literature must, therefore, be

\footnotetext{
${ }^{3}$ The books referred to here are Taylor Atkins's Blue Nippon: Authenticating Jazz in Japan (2001), Andrew Jones's Yellow Music: Media Culture and Colonial Modernity in the Chinese Jazz Age (2001), and Paul Austerlitz's Jazz Consciousness: Music, Race, and Humanity (2005). These works are significant examples of what Andy Fry refers to as a 'diasporic approach' to jazz research that provides a 'powerful' tool for 'analysing both the musical transformations that take place across borders and the unexpected significations the music sometimes takes on’ (Fry 2007: 340).
} 
reconciled with both its frequent use as a rhetorical trope in African-America speech and the uncertainty of its origins. This can be accomplished by accepting that Gates's The Signifying Monkey is successful as one theory of African-American literary criticism but may not serve to define all aspects of African-American literary process. If in applying one theory to a particular issue a certain understanding emerges and in applying another, a separate understanding emerges, the net knowledge of these interpretations frames the next empirical question.

I acknowledge that this reading of Gates's theory undermines part of the agenda on which it is built. As Ramsey dutifully points out, Gates's hypothesis needs to be viewed 'with respect to the cultural work it is performing for its creator[s] and its audience' (2001: 33). In following this line of thinking, the agenda of The Signfiying Monkey can be seen as an extension of a particular political bent, one in which the unification of African and African-American history is prioritized as the vehicle for scholarly ratification of African-American literature. Passages of The Signifying Monkey speak strongly to this hypothesis. As Gates's states in the preface to his work:

I had at last located within the African and AfroAmerican traditions a system of rhetoric and interpretation that could be drawn upon both as figures for a genuinely 'black' criticism and as frames through which I could interpret, or 'read,' theories of contemporary literary criticism. After several active years of work applying literary theory to African and AfroAmerican literatures, I realized that what had early on seemed to me to be the fulfillment of my project as a would-be theorist of black literature was, in fact, only a moment in a progression. The challenge of my project, if not exactly to invent a black theory, was to locate and identify how the 'black tradition' had theorized about itself. (Gates 1988: ix)

Gates’s insistence here that 'genuinely 'black' criticism' can only be found by looking to Africa elevates the importance of a particular racial strain in the development of African-American culture over strains indigenous to the Caribbean, the Americas and Europe. This connection in turn bestows authority on Gates's work by providing his theory with an historic (if potentially simplified) grounding in the already established field of African studies.

Rojas’s From Black Power to Black Studies (2007) offers several examples of similar strategic alignments in the development of African-American Studies programs at US universities during the 1990s. Unsurprisingly, Gates features prominently in this discussion as head of the African and African-American Studies department at Harvard, a tenure beginning in 1991 and ending in 2006. Rojas describes the restructuring of the 
department under Gates as one of the more successful endeavours in establishing a Black Studies presence at the university level. He attributes this success to Gates's creation of 'tracks allowing students to concentrate in either African or African American studies,' thus permitting 'Africanist and African-American scholars to use the same resources and interact with each other' (Rojas 2007: 125). In addition, Rojas points to the contributions of students and faculty to research projects promoting the relationship between Africa and the African diaspora as evidence of a strategic shift under Gates and Kwame Anthony Appiah’s editorial leadership. Africana: The Encyclopedia of the African and African American Experience (1999) is singled out as the definitive project of these collaborations.

If the goal of an essentialist alignment between Africa and AfroAmerica was the establishment of academic bodies willing to engage culturally appropriate tools in the analysis of African-American literature (or in fact to accept African-American literature as a legitimate field in the first place), then Gates appears to have been successful. Rojas indicates that the 'continuing existence of black studies programs' serves as evidence that social movements, like the one endorsed by Gates, have created 'durable spaces within mainstream institutions’ (Rojas 2007: 220). Certainly the derivatives of Gates's theory found in contemporary music scholarship discussed below demonstrate comfort with a less Afrocentric/activist view of the methodology. This is not to say that the fight for equal recognition of African-American cultural products is over; rather, it is simply meant to place the use of musical theories derived from the Signifyin(g) construct into a context that acknowledges the historical trajectory from which they emerged.

\section{Signifyin(g) in African-American musical discourse}

Gates foreshadowed the appropriation of his trope into the domain of musical analysis through his claim that 'there are so many examples of Signifyin(g) in jazz that one could write a formal history of its development on this basis alone' (Gates 1988: 63). He follows this comment with a depiction of jazz as a language akin to black vernacular English, developed through the identification of overlapping practices regarding repetition and revision in both mediums. Gates so confidently assumes the affinity of these aural traditions, he uses an allusion to the music of Count Basie to summarize the connection between African-American aural practices and his newly identified literary trope: 
Indirection is the most common feature of the definitions of Signifyin(g) that I have outlined in Chapter 2. Basie's composition allows us to see Signifyin(g) as the tradition's trope of revision as well as of figuration. Throughout his piece, Basie alludes to styles of playing that predominated in black music between 1920 and 1940. These styles include ragtime, stride, barrelhouse, boogiewoogie, and the Kansas City "walking bass" so central to swing in the thirties. Through these allusions, Basie has created a composition characterized by pastiche. He has recapitulated the very tradition out of which he grew and from which he descended. Basie, in other words, is repeating the formal history of his tradition within his composition entitled "Signify." It is this definition of Signify that allows for its use as a metaphor of Afro-American formal revision. (Gates 1988: 124)

Gates does not distinguish between African-American spoken and musical traditions in this passage, instead conflating them both in the sentence 'Basie's composition allows us to see Signifyin(g) as the tradition's trope of revision as well as of figuration' [italics mine]. (124) By depicting African-American music as synonymous with AfricanAmerican spoken vernacular, Gates negates the need to bridge a theoretical gap in applying his literary theory to the musical realm.

Ethnomusicologist Steven Feld had warned against this modal blending more than a decade earlier, claiming that: 'Most of the activity involving linguistic models in ethnomusicology falls into the hocus-pocus category’ (Feld 1974: 211). Feld's critique was aimed mainly at ethnomusicologists who derived overarching theories of musical construction based on perceptions of culturally specific linguistic parallels. The main problem with this approach was that researchers ignored 'issues like the empirical comparison of models, a matatheory of music, evaluation procedures, and the relation of the models to the phenomena they supposedly explain' (Feld 1974: 210). Although Feld's critique significantly predates Gates's work, it adumbrates a valid critique of Signifyin(g) as a master trope for the study of African-American music. Much like the ethnomusicologists Feld takes to task, Gates does not pursue any routes towards an empirical evaluation of his theory, instead allowing his many examples to stand as selfevident. In his assertions on music, the effects of this omission are even more extreme as the qualitative examples are fewer. However, if the linguistic/musical cross-over Gates refers to is removed from the context of an all encompassing theory of artistic expression and woven into the fabric of a complex array of devices available for use by African-American artists, then an imperative for empirical verification seems less urgent. Or more to the point, acknowledging that there may be multiple readings of what exactly comprises African-American artistic expression allows those of us working in Culture Studies to more freely indulge in the findings of qualitative researchers. 
In the area of linguistic/musical links in African-American culture, these qualitative studies have historically focused on the blurred lines between spoken and sung text in gospel services. Garland's (1969) account of the development of Soul music draws partly on this concept, describing the fusion of rhythmic speech and song as an important facet of soul musician Aretha Franklin's style. He claims that the 'incantatory use of rhythm' in her father's sermons 'ineradicably impressed’ her style (Garland 1969: 24), and supports this assertion with the following personal observation:

\begin{abstract}
In her singing and in her playing I have heard many of the techniques familiar to my own Baptist upbringing. Similarly, when Ray Charles comes to the end of a chorus and lets loose with a halfchanted and half-sung cluster of improvised lyrics building up to a screamed "Yeeeeee-aah!" that seems to batter at the very gates of heaven, whipping the audience into a state of deliciously unbearable tension that inflames it to the point of shouting back its own unison "Yeah" I am more than a little reminded of the prancing, perspiring, hymn-humming preachers of my youth who could take a list of biblical names, linking them only with the rhythmically injected word "begat," and produce such an intoxicating effect that the 'sisters' of the church would "get happy" and "shout," springing up from the pews. (Garland 1969: 24)
\end{abstract}

Garland's analysis is plainly subjective yet his description of similar rhetorical devices utilized by both the musician and the preacher are echoed in Heilbut’s (1971) discussion of the vernacular practices of gospel singers: 'When they talk among themselves, their language is a compound of tradition and innovation. Like the singing itself, it employs all manner of nonverbal aids_-moans, hums, chuckles—-to enhance communication' (Heilbut 1971: xxxii). Such early observations paved the way for more methodical investigations of linguistic/musical links in gospel services.

Williams-Jones's work models an ideal aesthetic for gospel singing based largely on the singer's extension of the preacher's rhetorical approach:

\footnotetext{
In seeking to communicate the gospel message, there is little difference between the gospel singer and the gospel preacher in the approach to his subject. The same techniques are used by the preacher and the singer - the singer perhaps being considered the lyrical extension of the rhythmically rhetorical style of the preacher. Inherent in this also is the concept of black rhetoric, folk expressions, bodily movement, charismatic energy, cadence, tonal range and timbre. (Williams-Jones 1975: 381)
}

One linguistic element given particular focus by Williams-Jones is the use of the folk expression 'worrying the line,' as described by Henderson (1973: 41), in which one alters the pitch of a note in a spoken passage. After claiming that 'Black speech is a significant aspect of the gospel performance idiom' (Williams-Jones 1975: 383), Williams-Jones demonstrates how worrying the line manifests in a musical context: 'As a solo technique, worrying the line is most often encountered in the gospel selections 
which are in slow tempo. This allows the maximum opportunity for the inventiveness of the soloist in improvisation and building an emotional climax' (Williams-Jones 1975: 383). Like Garland (1969) and Heilbut (1971), the comparative approach undertaken by Williams-Jones highlights links between the spoken and musical realms. However, by choosing a specific device instead of an overall aesthetic approach, she is able to more successfully argue for the connection.

Snead utilizes a similar method in his essay 'On Repetition in Black Culture’ (1981). Drawing largely on qualitative evidence assembled by Chernoff (1979), Snead concludes that repetition in black literature is informed by "musical' prototypes in the sense that repetition of words and phrases, rather than being overlooked' are 'exploited as a structural and rhythmic principle’ (Snead 1981: 151). These prototypes, in turn, link to rhetorical practices of the black church. To illustrate his point, he focuses on the musical device of 'the cut,' applied frequently in the music of James Brown:

\footnotetext{
The format of the Brown "cut” and repetition is similar to that of African drumming: After the band has been "cookin" in a given key and tempo, a cue, either verbal ("get down" or "Mayfield" - the sax player's name-or "watch it now”) or musical (a brief series of rapid, percussive drum and horn accents) then directs the music to a new level where it stays with more "cookin" or perhaps a solo- until a repetition of cues then "cuts" back to the primary tempo. (Snead 1981: 150)
}

The type of repetition discussed here is utilized for the structural purpose of shifting between textures in the work. The result of this approach is that Brown's music remains repetitive horizontally but manifests variation vertically (in this example Snead refers to the addition of a soloist as one textural permutation). Snead then turns to the pulpit of the black church to describe the rhetorical origin of this device:

\footnotetext{
Both preacher and congregation employ the "cut.” The preacher "cuts” his own speaking in interrupting himself with a phrase such as "praise God" (whose weight here cannot be at all termed denotative or imperative but purely sensual and rhythmic — an underlying 'social' beat provided for the congregation). The listeners, in responding to the preacher's calls at random intervals, produce each time they "cut," a slight shift in the texture of the performance. At various intervals a musical instrument such as the organ, and often spontaneous dancing, accompanies the speaker's repetition of the "cut.” When the stage of highest intensity comes, gravel-voiced "speaking in tongues” or the "testifying," usually delivered at a single pitch, gives credence to the hypothesis that all along the very texture of the sound and nature of the rhythm-but not the explicit meaning_in the spoken words have been at issue. (Snead 1981: 151)
}

Snead's assessment of the use of 'the cut' in this context demonstrates similarity to its use in the musical realm: it is employed to produce 'a slight shift in the texture of the performance' (1981: 151). While it may be impossible to demonstrate a fundamental 
principle of similarity in African-American linguistic and musical approachesespecially with the limitations of qualitative analysis outlined by Feld (1974)—Snead's observations do identify the use of similar structural tools in both mediums. The effect of these observations in combination with the comparative study of Williams-Jones (1975), and early observations of Garland (1969) and Heilbut (1971), result in a general consensus over the fundamental nature of African-American performative practices.

This context of established affinity between linguistic and musical models set the foundation for the use of Gates's theory in the arena of musical analysis. While it is not my intent to overemphasise the influence of research into Gospel practices as opposed to research into African-American linguistic practices on this methodological shift, it is worth noting that many of Gates's most vocal champions in the musical realm supported their use of his theory by referring to accepted linguistic/musical links in African-American religious settings. This type of legitimization permeates the comments of speakers during a 1993 roundtable discussion hosted by the Center for Black Music Research (CBMR), of which the expressed goal was to investigate the use of Gates's theory as a 'common mode of inquiry for the study of black artistic expression’ (Floyd 1995b: 5). Participant James Winn argued for the legitimacy of such pursuits by pointing out that: 'Black culture in America, both spoken and sung, did a remarkable job of transform[ing] ... the King James Bible.’ He continues by explaining that the text had been 'taken and made into something living and ... very often into something powerfully musical' as a result of the 'multi- or interdisciplinary process' (Winn 1995: 16). Jon Michael Spencer concurred, referencing the concept of transmodal African-American cultural products soon to be put forth in Michael Harris’s book The Rise of the Gospel Blues (1994). Mari Evans in turn cited the research on 'worrying the line' discussed in this article, claiming that 'tonal memory as poetic structure' and 'mascon structures endemic to both music and poetry' begged a 'common scholarship'(Evans 1995: 30). ${ }^{4}$

Even more directly, CBMR convener Samuel Floyd would use African American religious practices to justify his reliance on Signifyin(g) analyses in his 1995 book The Power of Black Music. This seminal work begins by exploring 'aspects of African

\footnotetext{
${ }^{4}$ The term 'mascon structures' is frequently used in African-American vernacular discourse as a synonym for past models of expression that continue to exert influence over artistic production.
} 
expressions in religious, musical and narrative contexts' in order to 'set the stage' for an 'understanding [of] how these expressions were transformed' in the world of AfricanAmerican music (Floyd 1995a: 10). Floyd establishes a link between language and music early on, drawing on Burlin’s (1919) account of spoken and sung call-andresponse figures in black worship ceremonies, Tonsor's (1892) claim of 'slave songs ... disappearing "before the triumphant march of Gospel Hyms,"” and Tindley’s (1905) modelling of hymn arrangements on African American rhetorical practices, from which he concludes: 'The spiritual and the black declamatory style went hand in hand, simply because they both emerged from the same source: African intonations, inflections, and rhythmic conventions applied to a new language and linguistic style in the context of a new religion' (Floyd 1995a: 62). With this parallel established, Floyd infers the existence of an all-encompassing African-American artistic tradition, replete with shared tropes and universal rhetorical principles. He supports this claim through further documentation of cross modal African-American cultural practices, building a foundation on which to base his appropriation of Gates’s literary theory.

The use of Gates's theory in Floyd's work is pivotal in the history of African-American music studies because it provided the field a tool it had long been without. Not only was the theory able to explain syncretic strategies prevalent throughout the history of African-American music development; more importantly, it was also able to bestow complete ownership to African-Americans syncretic products supposedly derived from European cultural practices. In support of this latter point, Floyd uses Houston Baker's (1987) work on AfroAmerican modernity to link the systematic use of 'metaphorical masks' during the Harlem Renaissance with Gates's concept of Signifyin(g). Baker uses as evidence the oratory style of Booker T. Washington, claiming that his success as a Harlem Renaissance figure stemmed from an ability to advocate for the advancement of African-Americans 'by stepping inside the white world's nonsense syllables with oratorical mastery' (Baker 1987: 25). The 'masks' Washington wore may have appeared to be white, but by taking up the 'tones of nonsense to earn a national reputation' Washington was able to win 'corollary benefits for the Afro-American masses' (Baker 1987: 33). This type of subversion links directly with Floyd's reading of the Signifyin(g) trope:

Signifyin(g) is a way of saying one thing and meaning another; it is a reinterpretation, a metaphor for the revision of previous texts and figures; it is tropological thought, repetition with a difference, 
the obscuring of meaning, all to achieve or reverse power, to improve situations and to achieve pleasing results for the signifier ...

In African-American music, musical figures Signify by commenting on other musical figures, on themselves, on performances of other music, on other performances of the same piece, and on completely new works of music. Moreover, genres Signify on other genres-ragtime on European and early European and American dance music; blues on the ballad; the spiritual on the hymn; jazz on blues and ragtime; gospel on the hymn, the spiritual, and blues; soul on rhythm and blues, rock 'n' roll, and rock music; bebop on swing, ragtime rhythms, and blues; funk on soul; rap on funk; and so on. (Floyd 1995a: 95)

In this explanation, Floyd identifies a musical strategy for the advancement of AfricanAmerican music. He suggests that syncretic African-American musical works are, in fact, purpose built vehicles utilizing the veneer of other genres in order to expand their reach and commercial presence. This argument fits easily inside Baker's concept of AfroAmerican modernity and it is a process that Floyd believes can be evidenced through musical analysis.

Indeed, his discussion of William Grant Still’s Afro-American Symphony (1930) [1970] demonstrates a manifestation of the double-voiced utterance in a musical work. This is achieved by illuminating the interaction of opposing forms, 'orational rhetoric and conformational structure,' evident in the integration 'of an original twelve-bar blues' within 'a sonata-allegro format' (Floyd 1995a: 253). The effect of this conflict creates, in words borrowed by Floyd, 'structured structure’ (Kramer 1990), 'concatenated' (Bonds 1991) with the goal of 'making "correct" the black presence within the larger sonata-allegro structure'(Floyd 1995a: 254). As a strategy for expanding the reach of African-American music, Floyd views Still's approach as a success, summarising its impact in the following terms: 'Fraught with dialogical, rhetorical troping, the entire work carries considerable semantic value ... The Afro-American Symphony effectively realized the goals of the Harlem Renaissance, with Still vindicating the faith of the movement's intellectuals and establishing himself as the first black composer of a successful symphony' (Floyd 1995a: 110). Floyd's development of Gates's theory in turn served as the theoretical foundation for Guthrie P. Ramsey’s (2003) conception of 'Afro-modernism,' in which competing social ideologies are seen to synthesize in musical works of the 1940s. The recent use of Ramsey's (2003) theory to contextualize the presence of contrasting musical tropes in the works of Duke Ellington and Miles Davis (Howland 2007; Magee 2007; Green 2008) stand not only as a testament to Gates's legacy but to the body of work that allowed Gates's ideas to be incorporated into the musical sphere in the first place. 
The point of this short article is not to prove that there is a connection between the rhetorical devices of African-American spoken vernacular and the formal structures of African-American music; rather my aim is to show that regardless of the empirical evidence, a consensus existed within the Cultural Studies community before the publication of Gates's theory regarding the affinity of these domains. This consensus allowed Gates’s Signifyin(g) concept to be applied with such frequency and confidence. Perhaps this popularity, at least as it manifests in the musical arena, is due to the fact that Gates's theory provided those of us who study African-American music with a tool we had long required. The tool allows us to explore the linguistic/musical cross-over from a perspective of encoded meanings rather than pure formalism. It is both culturally appropriate and well supported by decades of qualitative research, and it carries political weight for African-American studies as well as the means of uniting racial groups, as demonstrated eloquently in Gary Tomlinson's article ‘Cultural Dialogics and Jazz: A White Historian Signifies’ (1991). In any case, the Signifyin(g) tool has become ubiquitous to the study of African-American music despite its origins in the literary realm and this transition should be attributed not solely to Gates's intuition but also to the work of those documenting African-American Gospel practices in the decades before The Signifyin(g) Monkey.

\section{Reference List}

Abrahams, R. 1964, Deep Down in the Jungle: Black American Folklore from the Streets of Philadelphia. Folklore Associates, Hatboro, PA.

Appiah, K. A. \& Gates, H. L. 1999, Africana: The Encyclopedia of the African and African-American Experience. Basic Civitas, New York.

Atkins, T. 2001, Blue Nippon: Authenticating Jazz in Japan. Durham, Duke University Press.

Austerlitz, P. 2005, Jazz Consciousness: Music, Race, and Humanity. Connecticut, Wesleyan University Press.

Baker, H. 1987, Modernism and the Harlem Renaissance. University of Chicago Press, Chicago.

Berliner, P. 1994, Thinking in Jazz. University of Chicago Press, Chicago.

Bonds, M. E. 1991, Wordless Rhetoric: Musical Form and Metaphor of the Oration. Harvard University Press, Cambridge, MA.

Burlin, N. 1919, 'Negro Music at Birth,' The Musical Quarterly, vol. 5, no. 1, 86-89.

Chernoff, J. M. 1979, African Rhythm and African Sensibility: Aesthetics and Social Action in African Musical Idioms. Chicago, University of Chicago Press.

DeVeaux, S. 1991 'Constructing the Jazz Tradition: Jazz Historiography,' Black American Literature Forum, vol. 25, no. 3, 525-560.

Evans, M. 1995, 'The Roundtable on Integrative Inquiry,' Lennox Avenue, vol. 1, no. 1, 5-61.

Feld, S. 1974, 'Linguistic Models in Ethnomusicology,' Ethnomusicology, vol. 18, no. 2, 197-217.

Fenstermaker, A. 2008, Bridging the Gap Between (White) Metafiction and (Black) Self-Reflexivity. Unpublished Ph.D. dissertation, University of Rochester.

Floyd, S. 1995a, The Power of Black Music: Interpreting its History from Africa to the United States. Oxford University Press, New York.

Floyd, S. 1995b, ‘The Roundtable on Integrative Inquiry,' Lennox Avenue, vol. 1, no. 1, 5-61. 
Fry, A. 2007, 'Review of Jazz Consciousness: Music, Race and Humanity by Paul Austerlitz,' Music and Letters, vol 88. no. 2, 335-340.

Garland, P. 1969, The Sound of Soul. H. Regenery Co., Chicago.

Gates, H. L. 1988, The Signifying Monkey: A Theory of African-American Literary Criticism. Oxford University Press, New York.

Green, E. 2008, 'It Don’t Mean a Thing if it Ain’t Got That Grungestalt!—Ellington from a Motivic Perspective,' Jazz Perspectives, vol. 2, no. 2, 215-249.

Goss, L. \& Barnes, M. 1989, Talk That Talk: An Anthology of African-American Storytelling. Simon \& Schuster, New York.

Harris, M. 1992, The Rise of the Gospel Blues. Oxford University Press, New York.

Heilbut, A. 1971, The Gospel Sound: Good News and Bad Times. Simon \& Schuster, New York.

Henderson, S. 1973, Understanding the New Black Poetry; Black Speech and Black Music as Poetic Reference. Morrow, New York.

Howland, J. 2007, 'The Blues Get Glorified: Harlem Entertainment, Negro Nuances, and Black Symphonic Jazz,' The Musical Quarterly, vol. 90, no. 3/4, 319-370.

Hutcheon, L. 1989. The Politics of Postmodernism. Routledge, New York.

Jones, A. 2001, Yellow Music: Media Culture and Colonial Modernity in the Chinese Jazz Age. Duke University Press, Durham, NC, \& London.

Kramer, L. 1990, Music as Cultural Practice, 1800-1900. University of California Press, Berkeley.

Magee, J. 2007, 'Kinds of Blue: Miles Davis, Afro-Modernism, and the Blues,' Jazz Perspectives, vol. 1, no. 1, 5-27.

Mitchell-Kernan, C. 1972, 'Signfiying, Loud-Talking and Marking,' in Signifyin(g), Sanctifin', \& Slam Dunking: A Reader in African-American Expressive Culture. 1999, (ed.) G. D. Caponi, University of Massachusetts Press, Massachusetts, 309-330.

Murphy, J. P. 1990, 'Jazz Improvisation: The Joy of Influence,’ The Black Perspective in Music, vol. 18, no. $1 / 2,7-19$.

Myers, D. G. 1990, 'Signifying Nothing,’ New Criterion, vol. 8 (February), 61-64.

Ramsey, G. 2001, 'Who Hears Here? Black Music, Critical Bias, and the Musicological Skin Trade,' The Musical Quarterly, vol. 85, no. 1, 1-52.

Ramsey, G. P. 2003, Race Music: Black Culture from Bebop to Hip-Hop. University of California Press, Berkeley.

Rojas, F. 2007, From Black Power to Black Studies. John Hopkins University Press, Baltimore.

Smitherman, G. 1977, Talkin and Testifyin: The Language of Black America. Wayne State University Press, Detroit, MI.

Snead, J. A. 1981, 'On Repetition in Black Culture,' Black American Literature Forum, vol. 15, no. 4, 146-154.

Still, W. G. 1970, Afro-American Symphony, score, revised edition. Novello, London.

Tindley, C. 1905, New Songs of Paradise. E.T. Tindley, Lansing, MI.

Tomlinson, G. 1991, 'Cultural Dialogics and Jazz: A White Historian Signifies,' Black Music Research Journal, vol. 11, no. 2, 229-264.

Tonsor, J. 1892, ‘Negro Music,’ Music, vol. 3, 119-122.

Williams-Jones, P. 1975, 'Afro-American Gospel Music: A Crystallization of the Black Aesthetic,' Ethnomusicology, vol. 19, no. 3, 373-385.

Winn, J. 1995, ‘The Roundtable on Integrative Inquiry,' Lennox Avenue, vol. 1, no. 1, 5-61. 